\title{
A VISÃO DOS ESTUDANTES UNIVERSITÁRIOS DE ADMINISTRAÇÃO SOBRE EMPREENDEDORISMO: COMPARAÇÕES ENTRE O ESTUDO GUESSS BRASIL 2011 COM O LEVANTAMENTO REALIZADO NA UNIVERSIDADE ESTADUAL DE LONDRINA- PR
}

DOI: 1014211/regepe33003

\author{
Saulo Fabiano Amâncio Vieira - Universidade Estadual De Londrina ${ }^{1}$ \\ Gerson Antonio Melatti - Universidade Estadual De Londrina ${ }^{2}$ \\ Letícia Fernandes De Negreiros - Universidade Estadual De Londrina ${ }^{3}$ \\ Camila Moliani Ferri - Universidade Estadual De Londrina ${ }^{4}$
}

Resumo: A presente pesquisa busca comparar os resultados obtidos pelo Estudo GUESSS Brasil 2011 com um levantamento realizado junto aos discentes do Curso de Administração da Universidade Estadual de Londrina - UEL. De um total de 568 alunos matriculados, foram pesquisados $251(44,19 \%)$ estudantes, durante o período de abril a junho de 2011. A análise dos dados reproduz as variáveis do Estudo GUESSS Brasil, apresentando o perfil dos universitários, o contexto da IES, as intenções de carreira e motivações profissionais, a importância da opinião de pessoas próximas nas tomadas de decisões dos discentes, as informações sobre o negócio que os universitários pretendem iniciar e, por fim, o cálculo do índice de empreendedorismo. Pode-se perceber que os alunos pesquisados apresentam fortes características empreendedoras, porém, existem barreiras para a aplicação dessas características, principalmente no que tange à falta de possibilidades e acesso ao capital financeiro.

Palavras-chave: Empreendedorismo, Estudo GUESSS Brasil, Universitários.

\section{THE VISION OF THE ADMINISTRATION UNIVERSITY STUDENTS ABOUT ENTREPRENEURSHIP: COMPARISONS BETWEEN THE BRAZIL GUESSS STUDY 2011 WITH THE SURVEY CONDUCTED IN THE STATE UNIVERSITY OF LONDRINA - PR}

Abstract: This research seeks to compare the results of the Study GUESSS Brazil 2011 with a data collection among students of the Administration Course at the State University of Londrina - UEL. A total of 568 students enrolled, 251 were surveyed (44.19\%) during the period April to June 2011. The data analysis reproduces the variables of the Study GUESSS Brazil, presenting the profile of the university students, the context of the IES, the career

\footnotetext{
1 E.mail: saulo@uel.br - Endereço: Rodovia Celso Garcia Cid, Km 380 - Campus Universitário, Londrina - PR, CEP: 86057-970.

${ }^{2}$ E.mail: gmelatti@uel.br

${ }^{3}$ E.mail: leticia_negreiros@hotmail.com

${ }^{4}$ E.mail: camila_moliani@hotmail.com
}

VIERIA, S. F. A.; MELATTI, G. A.; NEGREIROS, L. F.; FERRI, C. M. A visão dos estudantes universitários de administração sobre empreendedorismo: comparações entre o estudo Guesss Brasil 2011 com o levantamento realizado na Universidade Estadual de LondrinaPR. Revista de Empreendedorismo e Gestão de Pequenas Empresas, v. 3, n. 3, p. 77103, 2014. 
intentions and professional motivations, the importance of the opinion of close people in decision making of the students, the information about the business that the students want to start and finally the calculate of the index of entrepreneurship. It can be noticed that the students surveyed have strong entrepreneurial characteristics, but are barriers to their implementation, especially regarding the lack of opportunities and access to financial capital.

Keywords: Entrepreneurship, Study GUESSS Brazil, University Students.

\section{Introdução}

O empreendedorismo é um termo que tem alcançado cada vez mais posição de destaque no mundo todo. Vários estudos de âmbito mundial demonstram sua relevância nas últimas décadas, sendo que no Brasil, o caráter empreendedor passou a ser considerado como um importante fator ligado ao desenvolvimento social e econômico a partir de 1990 (RELATÓRIO GUESSS BRASIL, 2011). Segundo a mesma fonte, esse fato foi incentivado pelas diversas dificuldades, principalmente econômicas, pelas quais o Brasil atravessou na década de 1980, incluindo a grande instabilidade econômica daquela época.

Nos últimos dez anos o empreendedorismo passou a ser visto como uma das possíveis vias para gerar novos negócios e estimular a criação de empregos (RELATÓRIO GUESSS BRASIL, 2011). Dessa maneira, a formação universitária voltada para desenvolver empregados qualificados não é suficiente. Então, agentes políticos e dirigentes universitários começaram a analisar a importância do empreendedorismo como tema de formação nas universidades (LIMA; RODRIGUES, 2008 apud RELATÓRIO GUESSS BRASIL, 2011).

Assim, pelo fato do empreendedorismo ser considerado como uma possibilidade para o desenvolvimento econômico, o ensino do tema vem sendo inserido nas matrizes curriculares de muitos cursos de graduação, notadamente nos de Administração.

O ensino de empreendedorismo começou em 1947, criado pela escola de Administração de Harvard (ROCHA; BACCHI, 2010). No Brasil, a primeira disciplina sobre o assunto, denominada "Novos Negócios", foi ofertada em 1981, pela Fundação Getúlio Vargas (FGV), em São Paulo, para um curso de MBA. Já na

VIERIA, S. F. A.; MELATTI, G. A.; NEGREIROS, L. F.; FERRI, C. M. A visão dos estudantes universitários de administração sobre empreendedorismo: comparações entre o estudo Guesss Brasil 2011 com o levantamento realizado na Universidade Estadual de LondrinaPR. Revista de Empreendedorismo e Gestão de Pequenas Empresas, v. 3, n. 3, p. 77103, 2014. 
graduação, a primeira disciplina também foi ofertada pela FGV, em 1984, e chamada de "Criação de Novos Negócios - Formação de Empreendedores" (DOLABELA, 1999, p. 54-55).

Guerra e Grazziotin (2010, apud RELATÓRIO GUESSS BRASIL, 2011) apuraram a oferta de disciplinas de empreendedorismo e verificaram que nas Instituições de Ensino Superior (IES) públicas há uma oferta maior do que nas Instituições de Ensino Superior privadas. Além disso, os autores concluíram que as disciplinas sobre empreendedorismo avançaram para além dos cursos de Administração, contemplando também outras áreas, como Computação, Engenharia, Turismo, Moda, Design, Relações Públicas, Química entre outras.

Dessa forma, tornou-se relevante analisar o espírito empreendedor dos alunos e como eles percebem a oferta do ensino de empreendedorismo ou a falta dele nas suas Universidades. Nesse sentido, este trabalho possui como objetivo comparar os resultados obtidos pelo Estudo GUESSS Brasil 2011 com um levantamento realizado junto aos discentes do Curso de Administração da Universidade Estadual de Londrina - UEL.

\section{Referencial teórico}

Primeiramente o estudo aborda o conceito de empreendedorismo e sua evolução no contexto brasileiro. No segundo momento, trabalha-se com uma revisão acerca do ensino de empreendedorismo.

\section{Empreendedorismo}

O termo empreendedorismo é algo novo, muito explorado neste século, mas ainda sem uma definição universalmente aceita. Não há consenso entre os autores, uma vez que, segundo Hisrich, Peters e Shepherd (2009, p. 30), "existem empreendedores em todas as áreas" e desta forma, cada autor observa o empreendedorismo sob seu prisma. Para tanto, é necessário definir o entendimento sobre o termo.

VIERIA, S. F. A.; MELATTI, G. A.; NEGREIROS, L. F.; FERRI, C. M. A visão dos estudantes universitários de administração sobre empreendedorismo: comparações entre o estudo Guesss Brasil 2011 com o levantamento realizado na Universidade Estadual de LondrinaPR. Revista de Empreendedorismo e Gestão de Pequenas Empresas, v. 3, n. 3, p. 77103, 2014. 
Hisrich, Peters e Shepherd (2009, p. 30) entendem que:

[...] empreendedorismo é o processo de criar algo novo com valor, dedicando o tempo e o esforço necessários, assumindo os riscos financeiros, psíquicos e sociais correspondentes e recebendo as consequentes recompensas da satisfação e da independência financeira e pessoal.

Dornelas (2005) complementa a visão dos autores ao afirmar que empreendedorismo envolve pessoas e processos que, em conjunto, levam à transformação de ideias em oportunidades.

Com base em tais entendimentos, empreendedorismo será tratado neste estudo como a criação de algo novo ou a busca por uma oportunidade no mercado, com o objetivo de alcançar determinado público, propondo um diferencial e tendo como contraproposta recompensas, tanto financeiras quanto pessoais.

Além disso, é importante entender o empreendedorismo como um processo que, de acordo com Hisrich, Peters e Sheperd (2009, p. 31), envolve mais do que tomar decisões relativas ao cotidiano da empresa. Para os autores, é preciso passar por quatro fases distintas. A primeira fase envolve a análise da oportunidade, seu contexto e as possibilidades de retorno. Em seguida, é preciso elaborar o plano de negócios que auxilia no bom planejamento do empreendimento. A terceira fase serve para determinar os recursos que serão necessários para o negócio e como serão obtidos. Por fim, é preciso implementar um estilo e estrutura administrativa para a mais nova empresa, determinando as variáveis para o sucesso $(\mathrm{HISRICH}$, PETERS; SHEPERD, 2009).

Em consonância, Dornelas (2005) acrescenta a presença de riscos no negócio, mas destaca que eles podem ser minimizados e alguns até previstos, de forma que as dificuldades e incertezas sejam conhecidas, para que seja possível planejar alternativas e estar preparado para eventualidades.

O processo empreendedor só se torna possível com a combinação de alguns fatores. Para esse processo ocorrer é necessário, segundo Machado (2010), que o país proporcione oportunidades e capacidades de empreender. Bosma e Levie (apud Machado, 2010) citam, por exemplo, as condições nacionais oferecidas,

VIERIA, S. F. A.; MELATTI, G. A.; NEGREIROS, L. F.; FERRI, C. M. A visão dos estudantes universitários de administração sobre empreendedorismo: comparações entre o estudo Guesss Brasil 2011 com o levantamento realizado na Universidade Estadual de LondrinaPR. Revista de Empreendedorismo e Gestão de Pequenas Empresas, v. 3, n. 3, p. 77103, 2014. 
como o crescimento econômico, crescimento da população, cultura e políticas nacionais de fomento ao empreendedorismo que podem servir como estímulo ao desenvolvimento de novos negócios.

Complementarmente, há as condições ofertadas pelo país para fomentar ou barrar as atividades empreendedoras, um fator crucial para o desenvolvimento dos negócios está centrado na figura do seu agente: o empreendedor. Dornelas (2005, p.21) enfatiza os empreendedores como "pessoas diferenciadas, que possuem motivação singular, apaixonadas pelo que fazem, não se contentam em ser mais um na multidão, querem ser reconhecidas e admiradas, referenciadas e imitadas, querem deixar um legado".

Diante da relevância do papel do empreendedor, torna-se necessário contextualizar sua atuação no cenário brasileiro. Assim, em termos absolutos, o Brasil possui cerca de 33 milhões de pessoas desempenhando alguma atividade empreendedora. Esses dados foram levantados em 2009 pelo GEM. Este fato demonstra a importância das atividades empreendedoras na economia nacional e como estas contribuem tanto para o desenvolvimento, como para geração de riquezas no país. Segundo Machado (2010) a taxa de empreendedorismo em estágio inicial no Brasil, em 2010, foi a mais alta da série histórica da pesquisa realizada pelo Global Entrepreneurship Monitor - GEM desde 2001.

Outros aspectos, porém, precisam ser observados com mais atenção. Dornelas (2005) destaca que o processo empreendedor pode ter duas origens: por oportunidade ou por necessidade. A primeira chamada de empreendedorismo por oportunidade, é aquela na qual o empreendedor sabe aonde quer chegar, possui um planejamento prévio do seu negócio, se estrutura visando a geração de lucros, emprego e riqueza, totalmente ligado ao desenvolvimento econômico do país (DORNELAS, 2005).

Já a segunda definição, chamada de empreendedorismo por necessidade, é quando o empreendedor se aventura a abrir um negócio próprio por falta de opções, por estar desempregado ou não achar ocupações para suas habilidades profissionais, ou seja, estar sem alternativas de trabalho. Neste caso, os

VIERIA, S. F. A.; MELATTI, G. A.; NEGREIROS, L. F.; FERRI, C. M. A visão dos estudantes universitários de administração sobre empreendedorismo: comparações entre o estudo Guesss Brasil 2011 com o levantamento realizado na Universidade Estadual de LondrinaPR. Revista de Empreendedorismo e Gestão de Pequenas Empresas, v. 3, n. 3, p. 77103, 2014. 
empreendimentos costumam ser bem mais informais, sem planejamento adequado e muitos possuem tendência ao fracasso (DORNELAS, 2005).

Deste modo, o fato de um país apresentar dados numericamente expressivos em relação ao empreendedorismo não quer dizer que possua um alto teor de geração de riqueza e inovação, uma vez que o contexto precisa ser analisado em conjunto e com maior profundidade. Um dos fatores que contribuem para essa análise mais ampla diz respeito à inovação dos produtos ou serviços. Este quesito também é avaliado pelo GEM, o qual vislumbrou que a grande maioria dos empreendedores brasileiros $(83,5 \%)$ considera que não há nada de novo no seu portfólio de produtos ou serviços.

Esse dado, segundo interpretação de Machado (2010, p.61), coloca o Brasil com um dos menores índices de novidade de produto entre todos os países participantes dessa pesquisa de caráter mundial. Este fato é preocupante, principalmente ao considerar o exposto por Dornelas:

[...] o momento atual pode ser chamado de a era do empreendedorismo, pois são os empreendedores que estão eliminando barreiras comerciais e culturais, encurtando distâncias, globalizando e renovando os conceitos econômicos, criando novas relações de trabalho e novos empregos, quebrando paradigmas e gerando riqueza para a sociedade (DORNELAS, 2005, p. 22).

Ou seja, pode-se dizer que o Brasil está atrasado nesta era em que o empreendedorismo ganha notoriedade. Percebe-se então, que apesar da taxa de empreendedorismo em estágio inicial ter sido a mais alta desde 2001, o país apresenta pouca inovação. Desta forma, torna-se cada vez mais substancial ensinar e avaliar o empreendedorismo nas universidades como tentativa de fomentar o empreendedorismo por oportunidade, fato que pode contribuir com maiores níveis de inovação e que aumentam as chances do negócio prosperar.

VIERIA, S. F. A.; MELATTI, G. A.; NEGREIROS, L. F.; FERRI, C. M. A visão dos estudantes universitários de administração sobre empreendedorismo: comparações entre o estudo Guesss Brasil 2011 com o levantamento realizado na Universidade Estadual de LondrinaPR. Revista de Empreendedorismo e Gestão de Pequenas Empresas, v. 3, n. 3, p. 77103, 2014. 
Ensino de empreendedorismo

Tendo em vista a nova realidade social, na qual cresce a cada ano o número de pessoas interessadas em empreender, deve-se buscar capacitar os candidatos a empreendedores, o que já ocorre em muitos países, inclusive no Brasil. Para atender a essa necessidade, Dornelas (2005, p. 40) aponta que um curso de empreendedorismo deve, entre outros fatores, oferecer entendimento sobre o processo empreendedor, identificação de oportunidades, habilidades empreendedoras necessárias, fontes de financiamento e preparação de plano de negócio.

Hoje, a educação empreendedora tomou proporções respeitáveis em termos de cursos e pesquisas acadêmicas e, segundo Hisrich, Peters e Shepard (2009), é cada vez maior o número de universidades e faculdades que oferecem algum curso em empreendedorismo. Assim, por meio de uma revisão empírica foi possível encontrar estudos que já trataram da questão do ensino do empreendedorismo nas universidades.

O trabalho de Greatti, Gralik, Vieira e Sela (2010), por exemplo, buscou descrever as expectativas de acadêmicos do curso de Administração de uma Universidade Estadual do Sul do Brasil no que se refere ao aprendizado em empreendedorismo. Através de uma análise quantitativa dos questionários aplicados aos alunos do curso de Administração da Universidade, descobriu-se que um percentual considerável de alunos ingressa no curso de Administração com a intenção de ter um negócio próprio. Estes alunos esperam uma formação voltada para atuação em todos os tipos de empresas e contam com um ambiente de relacionamento voltado para o empreendedorismo. Nessa linha, o curso pesquisado pode contribuir com a formação empreendedora dos alunos, mas existe a necessidade de aplicar práticas de ensino empreendedoras.

Rocha e Bacchi (2010) ampliaram o universo pesquisado e analisaram os conteúdos e as metodologias pedagógicas de disciplinas de empreendedorismo em Instituições de Ensino Superior (IES) da cidade de Fortaleza. Para isso, os autores realizaram uma pesquisa documental e verificaram os Cursos de Administração que

VIERIA, S. F. A.; MELATTI, G. A.; NEGREIROS, L. F.; FERRI, C. M. A visão dos estudantes universitários de administração sobre empreendedorismo: comparações entre o estudo Guesss Brasil 2011 com o levantamento realizado na Universidade Estadual de LondrinaPR. Revista de Empreendedorismo e Gestão de Pequenas Empresas, v. 3, n. 3, p. 77103, 2014. 
ofertavam em suas matrizes curriculares a disciplina de empreendedorismo. Assim, para os cursos que a ofertavam, os autores realizaram um procedimento analíticoteórico comparando os conteúdos, métodos e recursos pedagógicos dos programas das disciplinas.

Com isso, Rocha e Bacchi (2010) destacaram que uma parcela considerável das IES não contemplava o ensino de empreendedorismo e, entre as que ofertavam a disciplina, havia predomínio da aplicação dos processos tradicionais de ensino, como aulas expositivas e exercícios, em detrimento de outros métodos, como recomendações de leituras, depoimentos de empreendedores, teoria aplicada à realidade dos participantes, jogos, casos, teatro popular, entre outros. Os resultados indicaram uma formação incompleta do sujeito empreendedor ao prevalecerem aulas e recursos excessivamente teóricos.

Souza Neto et al. (2007), anos antes, já haviam identificado a importância do ensino do empreendedorismo aos estudantes do Curso de Administração, avaliando sua influência no potencial empreendedor dos alunos. Dessa forma, desenvolveram uma pesquisa em duas universidades do Rio de Janeiro, sendo uma pública e a outra privada. Os autores concluíram que o ensino técnico de empreendedorismo fez diferença no espírito empreendedor dos discentes. No entanto, o ensino da disciplina despertou o desejo de empreender apenas em quem já tinha condições sociais e culturais favoráveis.

Baseados na necessidade cada vez maior das universidades ofertarem a disciplina de empreendedorismo da forma mais completa possível, Lima, Lopes e Nassif (2012) propuseram identificar os desafios e as oportunidades para melhorar a educação superior em empreendedorismo, considerando-se a demanda e a intenção empreendedora dos estudantes. Os autores realizaram um survey com 29.186 questionários respondidos de 37 IESs. Eles concluíram que os estudantes brasileiros têm alta demanda por formação em empreendedorismo. Além disso, levantaram algumas recomendações para a melhoria do ensino na área, tal como favorecer a aprendizagem pela prática e pelas relações, fornecendo uma abordagem mais prática que inclua informações sobre sistemas de apoio e financiamento, além da ampliação e diversificação da oferta de disciplinas e atividades das IESs, o

VIERIA, S. F. A.; MELATTI, G. A.; NEGREIROS, L. F.; FERRI, C. M. A visão dos estudantes universitários de administração sobre empreendedorismo: comparações entre o estudo Guesss Brasil 2011 com o levantamento realizado na Universidade Estadual de LondrinaPR. Revista de Empreendedorismo e Gestão de Pequenas Empresas, v. 3, n. 3, p. 77103, 2014. 
aumento da proximidade e do contato com os empreendedores e sua realidade e, principalmente, a preparação dos professores.

Por fim, tem-se o trabalho de Vieira et al. (2011). Eles realizaram um levantamento da realidade do ensino de empreendedorismo como parte integrante dos projetos pedagógicos dos cursos de graduação em Administração no país, especialmente em relação às práticas didático-pedagógicas utilizadas e ao perfil acadêmico dos coordenadores do curso. A pesquisa contou com a participação de 135 instituições de ensino superior e destacou como principais resultados, o fato de que $88 \%$ dos participantes consideram a disciplina de empreendedorismo essencial para a formação do administrador e 63\% acreditam ser possível ensinar as características individuais necessárias a um empreendedor.

Os autores apresentam ainda que $57,04 \%$ das IES afirmaram que o ensino ocorre através de aulas teóricas e práticas, $27,41 \%$ somente por aulas teóricas, $2,22 \%$ somente por aulas práticas. Ademais, verificou-se que $84 \%$ dos cursos ofertam a disciplina a partir do sexto semestre, ou seja, no final do curso. Nesse sentido, pode-se citar como falha dos cursos, não acompanhar a implantação dos negócios desenvolvidos a partir dos trabalhos de conclusão de curso.

Desta forma, nota-se como a oferta de ensino em empreendedorismo no Brasil ainda não é suficiente, dada a demanda e relevância da formação empreendedora, que auxiliam no desenvolvimento e geração de riqueza no país.

\section{Metodologia do estudo GUESSS Brasil}

A sigla GUESSS, originada do inglês, remete a Global University Entrepreneurial Spirit Students' Survey, ou seja, refere-se ao levantamento mundial sobre o espírito empreendedor dos universitários. Por sua vez, o Estudo GUESSS Brasil levantou informações sobre o empreendedorismo no contexto dos universitários brasileiros (RELATÓRIO GUESSS BRASIL, 2011).

O estudo GUESSS teve início em 2003, na Suíça, na Universidade St. Gallen, estando até a presente data sob a responsabilidade do Swis Research Institute of Small Business and Entrepreneurship e do Center for Family Business da

VIERIA, S. F. A.; MELATTI, G. A.; NEGREIROS, L. F.; FERRI, C. M. A visão dos estudantes universitários de administração sobre empreendedorismo: comparações entre o estudo Guesss Brasil 2011 com o levantamento realizado na Universidade Estadual de LondrinaPR. Revista de Empreendedorismo e Gestão de Pequenas Empresas, v. 3, n. 3, p. 77103, 2014. 
citada Universidade. Na edição de 2011, participaram 26 países, totalizando mais de 90.000 respondentes. Em 2011, foi a primeira vez que o Brasil participou da pesquisa e com uma grande representatividade, já que quase um terço dos questionários foi respondido pelos universitários brasileiros. No Brasil o estudo foi conduzido pela UNINOVE, com recursos provenientes da CAPES.

A característica central do método do Estudo GUESSS Brasil é que ele é um levantamento (LIMA et al., 2011). No Estudo GUESSS Brasil, 37 IES participaram da pesquisa, entre elas a Universidade Estadual de Londrina (UEL). No caso brasileiro, o questionário foi aplicado de modo online, obtendo-se 29.186 respondentes, mas 3.319 foram considerados como inválidos, logo, foram consideradas 25.867 respostas. Deste total, 251 foram alunos do curso de administração da UEL. Do total de 568 alunos matriculados no Curso de Administração da UEL, foram pesquisados 251 alunos, segundo os critérios de adesão e acessibilidade, perfazendo uma amostra de $44,19 \%$.

O instrumento de coleta foi um questionário com 16 blocos de questões, de conteúdo padronizado internacionalmente pela Universidade de St. Gallen, adaptado para o português por Lima et al. (2011) e utilizado no Estudo GUESSS Brasil. O instrumento foi aplicado no Curso de Graduação em Administração da UEL pelos professores do grupo de pesquisa em ensino de empreendedorismo, no período de abril a junho de 2011, sendo os dados coletados via internet. Os alunos eram encaminhados ao laboratório de informática do curso de Administração da UEL e o link para a pesquisa encontrava-se aberto nos computadores.

Ao término do preenchimento do formulário de pesquisa, as respostas eram automaticamente encaminhadas para uma base de dados dos coordenadores da pesquisa GUESSS no Brasil. Posteriormente, após o período final da coleta de dados brasileira, os coordenadores da pesquisa no Brasil encaminharam uma planilha no Microsoft Excel, com os dados referentes aos alunos da UEL.

A análise dos dados foi feita utilizando-se de estatística descritiva, com auxílio do Microsoft Excel, de forma a organizar as variáveis para que fosse possível comparar os resultados com o Estudo GUESSS Brasil.

VIERIA, S. F. A.; MELATTI, G. A.; NEGREIROS, L. F.; FERRI, C. M. A visão dos estudantes universitários de administração sobre empreendedorismo: comparações entre o estudo Guesss Brasil 2011 com o levantamento realizado na Universidade Estadual de LondrinaPR. Revista de Empreendedorismo e Gestão de Pequenas Empresas, v. 3, n. 3, p. 77103, 2014. 
Análise dos resultados - Estudo GUESSS UEL

A seguir são demonstrados os principais resultados. A análise envolveu exclusivamente as respostas dos universitários do curso de Administração da UEL, totalizando 251 participantes.

\section{Dados pessoais básicos}

Em relação ao perfil dos respondentes, foram incluídos: faixa etária, gênero e estado civil. A faixa etária dos universitários do Curso de Administração da UEL é marcada pelos discentes com menos de 25 anos de idade (81\%). Este número se diferencia da faixa etária brasileira, que é em torno de $50 \%$ de estudantes com menos de 25 anos. Isto também se repete na quantidade dos universitários com mais de 30 anos. Enquanto no Brasil essa população é de mais de 27\%, no Curso de Administração da UEL gira em torno de 5\%. Existem também diferenças em relação à variável gênero, pois enquanto no Curso de Administração da UEL, o público masculino representa quase $60 \%$ contra apenas $40,2 \%$ do feminino, no Brasil, a situação é inversa, com o predomínio do gênero feminino (55,4\%).

Quanto ao estado civil dos universitários, não foi possível fazer um comparativo entre o Curso de Administração da UEL com a situação brasileira, pois no relatório do GUESSS nacional, tais dados não foram apresentados. De qualquer forma, cabe ressaltar que no Curso de Administração da UEL, o número de solteiros é bem representativo $(90,84 \%)$, contra $9,16 \%$ de pessoas casadas. Esse quadro deve predominar nas universidades brasileiras devido à reduzida faixa etária dos estudantes que ingressam em cursos superiores.

\section{Contexto da instituição de ensino}

Neste quesito, foi abordado o nível de formação dos universitários e o conhecimento sobre a oferta de disciplinas e atividades na IES de origem. Em âmbito nacional, houve respondentes que estavam cursando pós-doutorado $(0,4 \%)$

VIERIA, S. F. A.; MELATTI, G. A.; NEGREIROS, L. F.; FERRI, C. M. A visão dos estudantes universitários de administração sobre empreendedorismo: comparações entre o estudo Guesss Brasil 2011 com o levantamento realizado na Universidade Estadual de LondrinaPR. Revista de Empreendedorismo e Gestão de Pequenas Empresas, v. 3, n. 3, p. 77103, 2014. 
e MBA/especialização (3,4\%). Tais dados não foram encontrados no levantamento realizado no Curso de Administração da UEL.

Para melhor visualizar o conhecimento sobre a oferta de disciplinas e atividades nas IES, apresenta-se na Tabela 1, um comparativo entre a visão dos alunos do Curso de Administração da UEL e a apresentada no relatório do Estudo GUESSS BRASIL.

TABELA 1 - Conhecimento sobre a oferta de disciplinas e atividades nas IESs

\begin{tabular}{|c|c|c|c|c|c|c|c|}
\hline \multirow{2}{*}{$\begin{array}{l}\text { TIPO DE } \\
\text { OFERTA }\end{array}$} & \multirow[t]{2}{*}{ ITEM } & \multicolumn{3}{|c|}{ ADM UEL $(n=251)$} & \multicolumn{3}{|c|}{ BRASIL $(n=25867)$} \\
\hline & & Sim & Não & Não sei & Sim & Não & Não sei \\
\hline \multirow[t]{8}{*}{ Disciplinas } & $\begin{array}{l}\text { Empreendedorismo em } \\
\text { geral }\end{array}$ & $90,4 \%$ & $4,4 \%$ & $5,2 \%$ & $65,4 \%$ & $9,3 \%$ & $25,3 \%$ \\
\hline & Plano de negócios & $88,0 \%$ & $3,2 \%$ & $8,8 \%$ & $62,3 \%$ & $8,4 \%$ & $29,3 \%$ \\
\hline & Marketing empreendedor & $72,5 \%$ & $15,9 \%$ & $11,6 \%$ & $54,0 \%$ & $13,1 \%$ & $33,0 \%$ \\
\hline & $\begin{array}{l}\text { Inovação e geração de } \\
\text { ideias }\end{array}$ & $57,0 \%$ & $19,5 \%$ & $23,5 \%$ & $58,9 \%$ & $10,6 \%$ & $30,4 \%$ \\
\hline & $\begin{array}{l}\text { Financiamento para a } \\
\text { criação de empresas }\end{array}$ & $29,9 \%$ & $35,5 \%$ & $34,7 \%$ & $23,2 \%$ & $25,3 \%$ & $51,5 \%$ \\
\hline & $\begin{array}{l}\text { Empreendedorismo } \\
\text { social }\end{array}$ & $53,0 \%$ & $18,7 \%$ & $28,3 \%$ & $49,2 \%$ & $13,7 \%$ & $37,1 \%$ \\
\hline & $\begin{array}{l}\text { Empreendedorismo } \\
\text { tecnológico }\end{array}$ & $53,0 \%$ & $18,7 \%$ & $28,3 \%$ & $42,2 \%$ & $17,1 \%$ & $40,7 \%$ \\
\hline & Empresas familiares & $20,7 \%$ & $43,0 \%$ & $36,3 \%$ & $22,4 \%$ & $26,1 \%$ & $51,5 \%$ \\
\hline \multirow[t]{5}{*}{$\begin{array}{l}\text { Atividades } \\
\text { de apoio }\end{array}$} & $\begin{array}{l}\text { Workshops/networking } \\
\text { com empreendedores }\end{array}$ & $48,2 \%$ & $23,5 \%$ & $28,3 \%$ & $40,1 \%$ & $18,5 \%$ & $41,5 \%$ \\
\hline & $\begin{array}{l}\text { Programas de mentoria e } \\
\text { coaching para } \\
\text { empreendedores }\end{array}$ & $15,9 \%$ & $34,5 \%$ & $49,8 \%$ & $19,6 \%$ & $22,4 \%$ & $58,0 \%$ \\
\hline & $\begin{array}{l}\text { Concurso ou workshops } \\
\text { de planos de negócios }\end{array}$ & $25,1 \%$ & $30,7 \%$ & $44,2 \%$ & $62,3 \%$ & $8,4 \%$ & $29,3 \%$ \\
\hline & $\begin{array}{l}\text { Área ou pessoa de } \\
\text { referência para tirar } \\
\text { dúvidas e dar apoio em } \\
\text { empreendedorismo }\end{array}$ & $50,6 \%$ & $19,1 \%$ & $30,3 \%$ & $38,2 \%$ & $17,4 \%$ & $44,4 \%$ \\
\hline & $\begin{array}{l}\text { Base para contato com } \\
\text { investidores potenciais }\end{array}$ & $16,3 \%$ & $41,0 \%$ & $42,6 \%$ & $19,6 \%$ & $25,8 \%$ & $54,6 \%$ \\
\hline \multirow[t]{2}{*}{$\begin{array}{l}\text { Oferta de } \\
\text { recursos }\end{array}$} & $\begin{array}{l}\text { Recursos tecnológicos e } \\
\text { de pesquisa (biblioteca, } \\
\text { internet) }\end{array}$ & $88,8 \%$ & $4,4 \%$ & $6,8 \%$ & $83,8 \%$ & $4,6 \%$ & $11,6 \%$ \\
\hline & $\begin{array}{l}\text { Capital inicial ou apoio } \\
\text { financeiro vindo da IES. }\end{array}$ & $13,1 \%$ & $42,6 \%$ & $44,2 \%$ & $19,7 \%$ & $29,7 \%$ & $50,6 \%$ \\
\hline
\end{tabular}

Fonte: elaborado pelos autores (2014)

Em relação ao conhecimento da oferta de disciplina/atividade é possível ver, de modo geral, que o Curso de Administração da UEL, de agora em diante nominado ADM UEL, tem porcentagens superiores aos levantados na pesquisa VIERIA, S. F. A.; MELATTI, G. A.; NEGREIROS, L. F.; FERRI, C. M. A visão dos estudantes universitários de administração sobre empreendedorismo: comparações entre o estudo Guesss Brasil 2011 com o levantamento realizado na Universidade Estadual de LondrinaPR. Revista de Empreendedorismo e Gestão de Pequenas Empresas, v. 3, n. 3, p. 77103, 2014. 
nacional, identificada como BRASIL. Assim, em amarelo estão sinalizados os itens em que o curso ADM UEL obteve desempenho inferior ao do BRASIL. Percebe-se que a maior falha da ADM UEL está na oferta das atividades de apoio e a maior diferença, quando comparada com o BRASIL, está na oferta de concursos ou workshops de plano de negócios (25,1\% contra 62,3\%).

As respostas em azul indicam a falta de oferta da disciplina/atividade em que ADM UEL obteve porcentagem maior do que as IESs do BRASIL. Por consequência, visualiza-se que no BRASIL houve maior representatividade dos alunos que não souberam responder a essa questão, sendo destacada em verde a única opção na qual a ADM UEL apresentou um índice maior. Aos alunos que responderam que a disciplina/atividade não era ofertada, foi perguntado se consideravam necessário introduzi-la na grade do curso. A Tabela 2 ilustra essas respostas:

TABELA 2 - Demanda de disciplinas e atividades ainda não oferecidas nas IES

\begin{tabular}{|c|c|c|c|c|c|}
\hline \multirow{2}{*}{$\begin{array}{l}\text { TIPO DE } \\
\text { OFERTA }\end{array}$} & \multirow[t]{2}{*}{ ITEM } & \multicolumn{2}{|c|}{ ADM UEL } & \multicolumn{2}{|c|}{ BRASIL } \\
\hline & & Gostaria & Não precisa & Gostaria & Não precisa \\
\hline \multirow[t]{8}{*}{ Disciplinas } & Empreendedorismo em geral & $87,5 \%$ & $12,5 \%$ & $75,4 \%$ & $24,6 \%$ \\
\hline & Plano de negócios & $90,0 \%$ & $10,0 \%$ & $81,4 \%$ & $18,6 \%$ \\
\hline & Marketing empreendedor & $91,3 \%$ & $8,7 \%$ & $73,4 \%$ & $26,6 \%$ \\
\hline & Inovação e geração de ideias & $96,3 \%$ & $3,7 \%$ & $85,4 \%$ & $14,6 \%$ \\
\hline & $\begin{array}{l}\text { Financiamento para a criação } \\
\text { de empresas }\end{array}$ & $87,5 \%$ & $12,5 \%$ & $75,8 \%$ & $24,2 \%$ \\
\hline & Empreendedorismo social & $81,4 \%$ & $18,6 \%$ & $85,4 \%$ & $14,6 \%$ \\
\hline & $\begin{array}{l}\text { Empreendedorismo } \\
\text { tecnológico }\end{array}$ & $87,3 \%$ & $12,7 \%$ & $71,5 \% \%$ & $28,5 \%$ \\
\hline & Empresas familiares & $69,8 \%$ & $30,2 \%$ & $60,7 \%$ & $39,3 \%$ \\
\hline \multirow[t]{5}{*}{$\begin{array}{l}\text { Atividades } \\
\text { de apoio }\end{array}$} & $\begin{array}{l}\text { Workshops/networking com } \\
\text { empreendedores }\end{array}$ & $92,3 \%$ & $7,7 \%$ & $75,9 \%$ & $24,1 \%$ \\
\hline & $\begin{array}{l}\text { Programas de mentoria e } \\
\text { coaching para } \\
\text { empreendedores }\end{array}$ & $86,3 \%$ & $13,7 \%$ & $70,9 \%$ & $29,1 \%$ \\
\hline & $\begin{array}{l}\text { Concurso ou workshops de } \\
\text { planos de negócios }\end{array}$ & $86,2 \%$ & $13,8 \%$ & $73,8 \%$ & $26,2 \%$ \\
\hline & $\begin{array}{l}\text { Área ou pessoa de referência } \\
\text { para tirar dúvidas e dar apoio } \\
\text { em empreendedorismo }\end{array}$ & $91,1 \%$ & $8,9 \%$ & $80,8 \%$ & $19,2 \%$ \\
\hline & $\begin{array}{l}\text { Base para contato com } \\
\text { investidores potenciais }\end{array}$ & $92,9 \%$ & $7,1 \%$ & $76,1 \%$ & $23,9 \%$ \\
\hline \multirow[t]{2}{*}{$\begin{array}{l}\text { Oferta de } \\
\text { recursos }\end{array}$} & $\begin{array}{l}\text { Recursos tecnológicos e de } \\
\text { pesquisa (biblioteca, internet) }\end{array}$ & $85,7 \%$ & $14,3 \%$ & $78,6 \%$ & $21,4 \%$ \\
\hline & $\begin{array}{l}\text { Capital inicial ou apoio } \\
\text { financeiro vindo da IES. }\end{array}$ & $84,4 \%$ & $15,6 \%$ & 80,7 & $19,3 \%$ \\
\hline
\end{tabular}

Fonte: elaborado pelos autores (2014)

VIERIA, S. F. A.; MELATTI, G. A.; NEGREIROS, L. F.; FERRI, C. M. A visão dos estudantes universitários de administração sobre empreendedorismo: comparações entre o estudo Guesss Brasil 2011 com o levantamento realizado na Universidade Estadual de LondrinaPR. Revista de Empreendedorismo e Gestão de Pequenas Empresas, v. 3, n. 3, p. 77103, 2014. 
Observando-se os dados de forma preliminar, pode-se inferir que os estudantes do Curso de Administração da UEL parecem mais motivados do que os universitários brasileiros a fazerem disciplinas e atividades que indicaram como não sendo atualmente oferecidas pela sua Instituição. A única exceção foi "empreendedorismo social", mas apresentou pouca diferença entre os respondentes.

\section{Intenções de carreira}

Quanto às intenções de carreira para logo após a formatura, 28,1\% dos respondentes da ADM UEL desejam trabalhar em uma grande empresa. Em seguida, aparece o desejo de trabalhar em uma pequena ou média empresa (15,3\%) e no serviço público, com 13,9\%. Percebe-se uma irregularidade maior na intenção de dar continuidade à empresa dos pais/parentes, em que a ADM UEL somou 8,0\% contra 3,3\% dos estudantes brasileiros. Além disso, na pesquisa BRASIL, os estudantes citaram a opção de montar uma franquia $(1,1 \%)$, fato que não apareceu entre os respondentes do Curso de Administração da UEL.

Foi possível avaliar que essas intenções diferem do desejo dos alunos de ADM UEL para após cinco anos de formados. Percebe-se que, nessa situação, diminui a intenção de trabalhar como funcionário em uma empresa (seja ela pequena, média ou grande) e cresce, particularmente entre os alunos de ADM UEL, a porcentagem dos que pretendem trabalhar no serviço público e ainda mais fortemente, o intuito de ser dono do próprio negócio, seja fundando a própria empresa, abrindo uma franquia ou adquirindo uma empresa não controlada pela família.

A Figura 1 apresenta um panorama geral das intenções de carreira dos universitários, comparando os dados levantados nos dois estudos: Estudo GUESSS BRASIL x recorte feito no Curso de Administração da UEL (ADM UEL).

VIERIA, S. F. A.; MELATTI, G. A.; NEGREIROS, L. F.; FERRI, C. M. A visão dos estudantes universitários de administração sobre empreendedorismo: comparações entre o estudo Guesss Brasil 2011 com o levantamento realizado na Universidade Estadual de LondrinaPR. Revista de Empreendedorismo e Gestão de Pequenas Empresas, v. 3, n. 3, p. 77 103, 2014. 
Empregado Fundador Sucessor $\square$ Outro

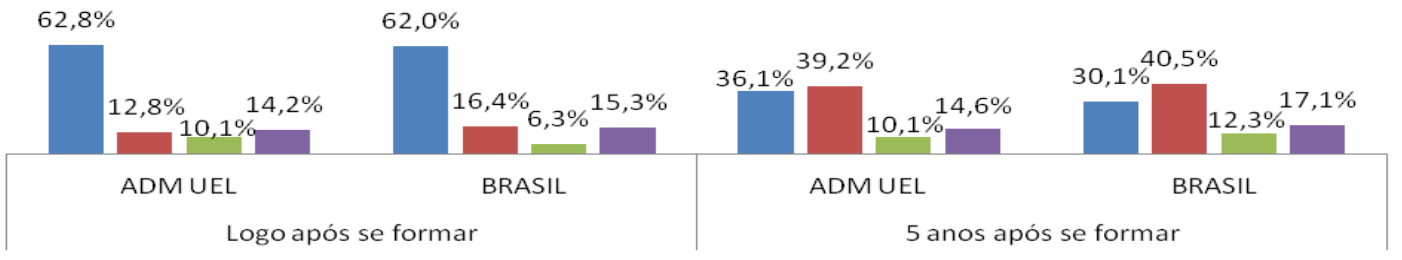

FIGURA 1 - Panorama geral das diferenças de intenção de carreira (em \%)

Fonte: elaborado pelos autores (2014)

A Figura 1 facilita a visualização sobre a mudança na intenção dos estudantes após cinco anos de formados. A principal marca é a passagem de "empregado" para "fundador" do negócio, tanto em nível nacional quanto nas intenções dos estudantes do Curso de Administração da UEL.

Outro fator que apresentou alteração pelos estudantes brasileiros, foi o aumento no intuito de ser sucessor, que passou de 6,3\% para $12,3 \%$. As outras intenções apresentam resultados próximos para os diferentes momentos da transição da universidade para o mercado de trabalho.

\section{Motivações para a escolha da carreira e para o trabalho futuro}

Os dados apresentados a seguir, na Figura 2, estão relacionados às questões que buscavam verificar os motivos que levam os universitários a escolherem o campo de trabalho futuro, direcionando seu planejamento de carreira profissional.

VIERIA, S. F. A.; MELATTI, G. A.; NEGREIROS, L. F.; FERRI, C. M. A visão dos estudantes universitários de administração sobre empreendedorismo: comparações entre o estudo Guesss Brasil 2011 com o levantamento realizado na Universidade Estadual de LondrinaPR. Revista de Empreendedorismo e Gestão de Pequenas Empresas, v. 3, n. 3, p. 77103, 2014. 


\section{A Revista da ANEGEPE

- BRASIL a ADMUEL

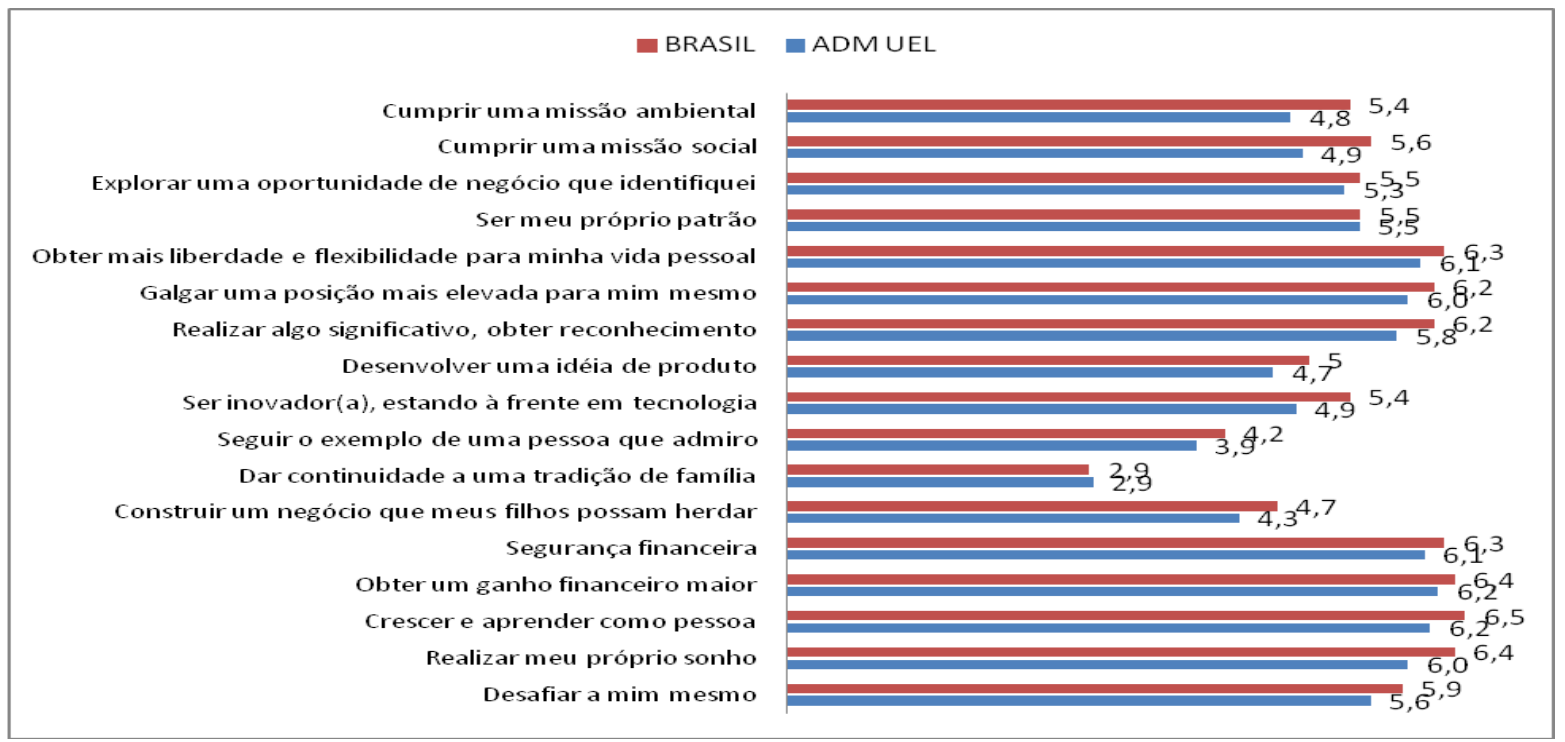

FIGURA 2 - Motivação dos universitários para escolher a carreira e trabalho futuro (em \%) Fonte: elaborado pelos autores (2014)

As notas atribuídas às questões representadas na Figura 2 mostram as médias das respostas coletadas junto aos respondentes, que deveriam considerar a nota 1 para "muito insignificante" e 7 para "muito importante". Percebe-se que as médias dos estudantes brasileiros estão mais altas do que as dos alunos do Curso de Administração da UEL, com exceção da opção "dar continuidade a uma tradição de família", em que a pontuação foi idêntica $(2,9)$, além de esse item ter sido considerado como o menos relevante pelos universitários para a escolha da carreira.

\section{Vontade de ser empreendedor}

Os estudantes foram indagados sobre o quanto seriamente têm pensado em criarem seus próprios negócios. A análise das respostas pode ser observada na Figura 3:

VIERIA, S. F. A.; MELATTI, G. A.; NEGREIROS, L. F.; FERRI, C. M. A visão dos estudantes universitários de administração sobre empreendedorismo: comparações entre o estudo Guesss Brasil 2011 com o levantamento realizado na Universidade Estadual de LondrinaPR. Revista de Empreendedorismo e Gestão de Pequenas Empresas, v. 3, n. 3, p. 77103, 2014. 


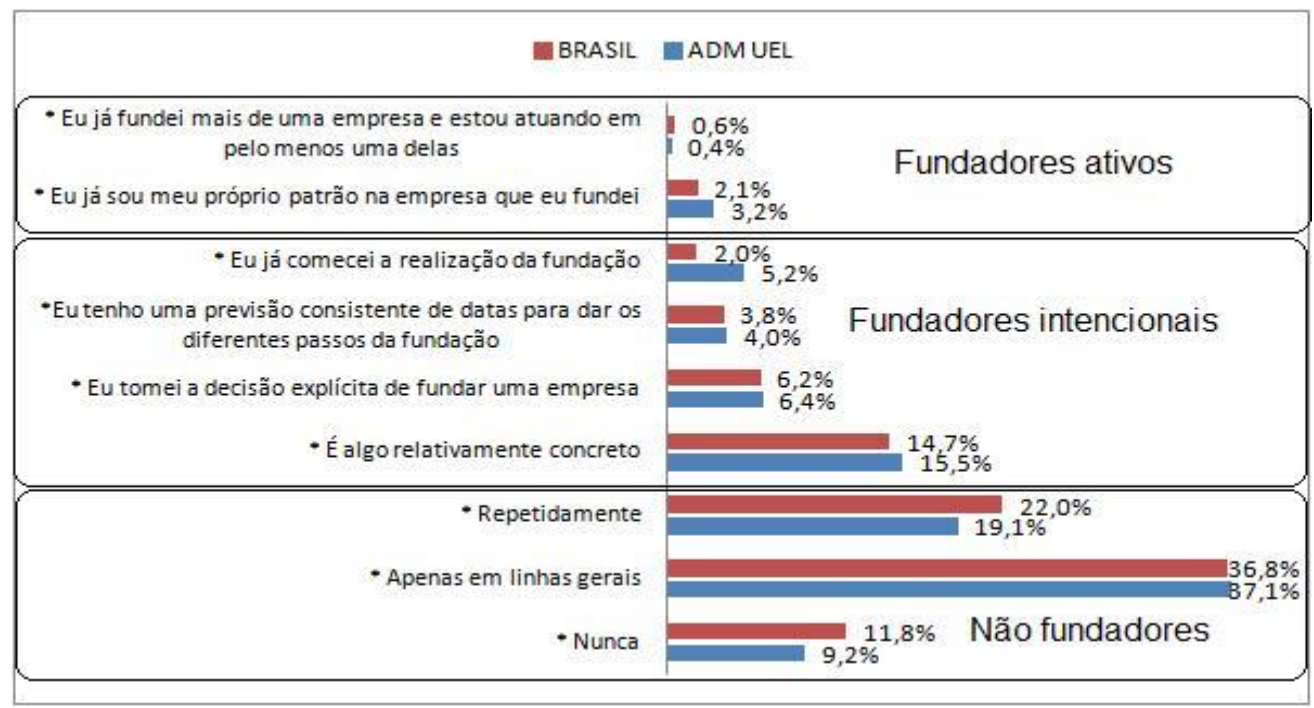

FIGURA 3 - O quão seriamente tem pensado em criar seu próprio negócio (em \%) Fonte: elaborado pelos autores (2014)

O relatório do Estudo GUESSS Brasil possibilitou a seleção das respostas em fundadores ativos, fundadores intencionais e não fundadores. Assim, segundo tal classificação, os alunos do Curso de Administração da UEL, categorizados como fundadores ativos, somam apenas $3,6 \%$. Já os fundadores intencionais totalizam $31,1 \%$ e os classificados como não fundadores somam $65,4 \%$. Estes pontos percentuais encontram-se bem próximos à realidade brasileira, representada pelo Estudo GUESSS Brasil, que foram 2,7 \%, 26,7 \% e 70,6\%, respectivamente.

$\mathrm{O}$ fato da maioria dos respondentes ser considerada como não fundadores apresenta uma contradição, pois quando questionados sobre a concordância com algumas afirmações apresentadas, os universitários apresentam visões positivas sobre o fato de empreender, como sendo uma carreira atrativa e de grande satisfação.

TABELA 3 - Concordância com algumas afirmações sobre se tornar um empreendedor

\begin{tabular}{lc}
\hline & MÉDIA \\
\hline Para mim, ser um empreendedor implica em mais vantagens do que & 5,32 \\
desvantagens para mim. & 5,37 \\
Uma carreira como empreendedor é atrativa para mim. & 5,68 \\
Se tivesse a oportunidade e os recursos, eu me tornaria um empreendedor. & 5,68 \\
Ser um empreendedor traria grande satisfação para mim. &
\end{tabular}

VIERIA, S. F. A.; MELATTI, G. A.; NEGREIROS, L. F.; FERRI, C. M. A visão dos estudantes universitários de administração sobre empreendedorismo: comparações entre o estudo Guesss Brasil 2011 com o levantamento realizado na Universidade Estadual de LondrinaPR. Revista de Empreendedorismo e Gestão de Pequenas Empresas, v. 3, n. 3, p. 77103, 2014. 
Para responder a estas perguntas, os universitários poderiam assinalar desde a nota 1 como "discordo totalmente" até a nota 7 para "concordo totalmente". As médias de todas as alternativas ficaram acima de 5 pontos, o que caracteriza uma boa percepção dos respondentes sobre a figura de um empreendedor.

\section{Importância da opinião de pessoas próximas}

Nesta parte, o questionário levanta a importância da opinião das pessoas a respeito da intenção de se tornarem empreendedores, os universitários poderiam escolher a nota 1 como "nem um pouco importante" e nota 7 para "muitíssimo importante".

TABELA 4 - Importância da opinião de pessoas próximas

\begin{tabular}{|c|c|c|c|c|c|c|c|c|}
\hline & 1 & 2 & 3 & 4 & 5 & 6 & 7 & MÉDIA \\
\hline $\begin{array}{l}\text { Pais/ outros } \\
\text { membros da } \\
\text { família }\end{array}$ & $2,40 \%$ & $2,00 \%$ & $4,40 \%$ & $7,20 \%$ & $13,50 \%$ & $21,90 \%$ & $48,60 \%$ & 5,88 \\
\hline $\begin{array}{l}\text { Colegas } \\
\text { estudantes/ } \\
\text { amigos }\end{array}$ & $6,40 \%$ & $9,20 \%$ & $10,00 \%$ & $20,70 \%$ & $24,30 \%$ & $16,70 \%$ & $12,70 \%$ & 4,49 \\
\hline $\begin{array}{l}\text { Pessoas } \\
\text { importantes } \\
\text { para mim em } \\
\text { geral }\end{array}$ & $2,80 \%$ & $2,80 \%$ & $8,00 \%$ & $12,40 \%$ & $21,90 \%$ & $21,50 \%$ & $30,70 \%$ & 5,35 \\
\hline
\end{tabular}

Fonte: elaborado pelos autores (2014)

Constatou-se que eles consideram, segundo as médias obtidas e relacionadas na Tabela 4 , a opinião dos pais e familiares $(5,88)$ como fator mais importante. Em segundo lugar, a opinião de pessoas que consideram importantes nos seus relacionamentos (5,35). Por último, a opinião de amigos e colegas de estudos $(4,49)$.

\section{Universitários que pretendem ser empreendedores}

O maior desejo dos alunos do Curso de Administração da UEL está em atuar nas áreas de marketing/propaganda (31,7\%), hotéis e restaurantes $(13,0 \%)$ e

VIERIA, S. F. A.; MELATTI, G. A.; NEGREIROS, L. F.; FERRI, C. M. A visão dos estudantes universitários de administração sobre empreendedorismo: comparações entre o estudo Guesss Brasil 2011 com o levantamento realizado na Universidade Estadual de LondrinaPR. Revista de Empreendedorismo e Gestão de Pequenas Empresas, v. 3, n. 3, p. 77103, 2014. 
consultoria $(11,4 \%)$. Outro dado que merece atenção diz respeito ao tempo de experiência que os universitários exerceram atividades em áreas relacionadas àquelas do negócio que pretendem abrir. Verificou-se que a grande maioria, tanto para ADM UEL (56,7\%) quanto para BRASIL (70,3\%), não possuem experiência no setor em que pretendem atuar.

Caso iniciem algum negócio próprio, a maior parte dos alunos de ADM UEL $(44,4 \%)$ optaria pela presença de 1 sócio na empresa e 38,1\% afirmaram que não teriam sócios. Além disso, a fonte de financiamento mais indicada pelos respondentes seria através de recursos próprios $(46,8 \%)$ e capital vindo da família e amigos $(21,0 \%)$. Somente em terceiro lugar aparecem os empréstimos bancários $(16,4 \%)$. A maior barreira para empreender no entendimento dos alunos de ADM UEL, está na falta de acesso ao capital de financiamento (com ou sem juros), seguido pelo risco financeiro e pela legislação do país.

Dentre aqueles que pretendem abrir um negócio, visualizou-se pouca disparidade entre as respostas acerca das origens da ideia do empreendimento - do próprio empreendedor ou de colegas universitários (33,3\%), de membros da família $(27,8 \%)$, dos estudos universitários (27\%), de hobbies ou atividade recreativa $(25,4 \%)$, do trabalho atual ou anterior $(21,4 \%)$ e de amigos fora do contexto universitário (15,1\%), com exceção para a opção "pesquisa acadêmica, científica ou aplicada", que obteve apenas $2,4 \%$ do total. Vale ressaltar que nessa questão poderia ser assinalada mais de uma alternativa, por isso, a somatória ultrapassa os $100 \%$.

\section{Índice de empreendedorismo}

O índice de empreendedorismo foi mais uma variável importante apresentada no relatório do Estudo GUESSS Brasil 2011 e replicada na pesquisa com os estudantes do Curso de Administração da UEL, sendo calculada através das seguintes categorias: médias dos não fundadores, fundadores intencionais e fundadores ativos, já apresentadas no tópico 4.5, aferindo pesos diferentes para cada uma delas, conforme se verifica na Tabela 5.

VIERIA, S. F. A.; MELATTI, G. A.; NEGREIROS, L. F.; FERRI, C. M. A visão dos estudantes universitários de administração sobre empreendedorismo: comparações entre o estudo Guesss Brasil 2011 com o levantamento realizado na Universidade Estadual de LondrinaPR. Revista de Empreendedorismo e Gestão de Pequenas Empresas, v. 3, n. 3, p. 77103, 2014. 
TABELA 5 - Interesse em empreender e pesos para se definir o índice de empreendedorismo

\section{Nunca} OPÇÃO DE RESPOSTA PESO

Apenas em linhas gerais

Repetidamente

1

1

É algo relativamente concreto

Eu tomei a decisão explícita de fundar uma empresa

Eu tenho uma previsão consistente de datas para dar os diferentes passos da fundação

Eu já comecei a realização da fundação

Eu já sou meu próprio patrão na empresa que eu fundei

Eu já fundei mais de uma empresa e estou atuando em pelo menos uma delas

Fonte: Sieger, Fueglistaller e Zellweger (2011) apud Relatório GUESSS Brasil (2011).
CATEGORIA

Não fundadores

Fundadores intencionais

Fundadores intencionais

Fundadores intencionais

Fundadores intencionais

Fundadores intencionais

Fundadores ativos

Fundadores ativos

Além disso, para cálculo do índice de empreendedorismo também são analisados quais os passos que já foram dados pelos universitários na intenção da criação do próprio negócio, atribuindo-se também pesos diferentes para cada um deles.

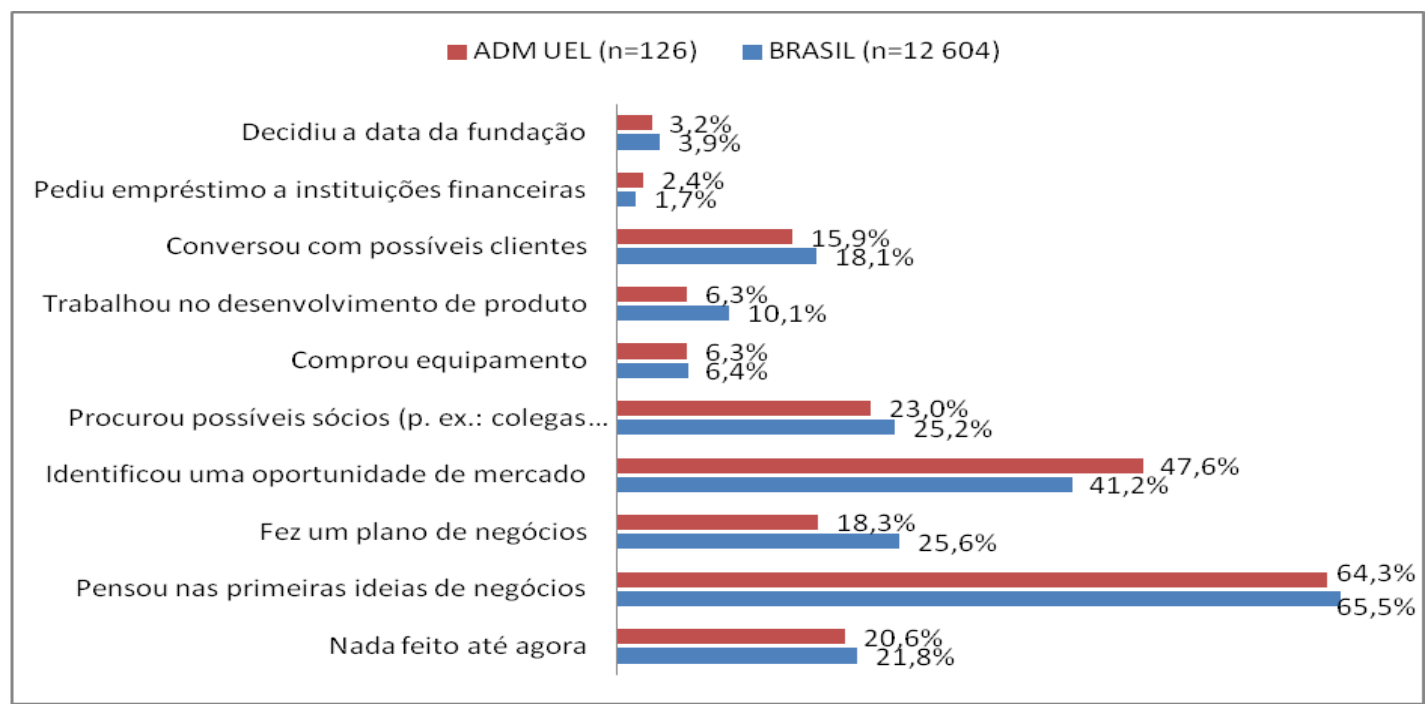

FIGURA 4 - Passos já dados para criar o próprio negócio

Fonte: elaborado pelos autores (2014)

Vale ressaltar que nesse quesito, os estudantes poderiam assinalar mais de uma opção. Como resultado, pode-se perceber que grande parte dos discentes pensou nas primeiras ideias de negócios (64,3\%), seguido pelos que já identificaram uma oportunidade de mercado $(47,6 \%)$, aqueles que já procuraram possíveis sócios $(23 \%)$ e aqueles que ainda nada fizeram (20,6\%). Notou-se também pouca diferença

VIERIA, S. F. A.; MELATTI, G. A.; NEGREIROS, L. F.; FERRI, C. M. A visão dos estudantes universitários de administração sobre empreendedorismo: comparações entre o estudo Guesss Brasil 2011 com o levantamento realizado na Universidade Estadual de LondrinaPR. Revista de Empreendedorismo e Gestão de Pequenas Empresas, v. 3, n. 3, p. 77103, 2014. 
entre os dados levantados junto aos respondentes de ADM UEL em comparação com os resultados da pesquisa nacional.

Na Tabela 6, a seguir, constam os pesos atribuídos a estas questões.

TABELA 6 - Preparação para empreender e pesos para se definir o índice de empreendedorismo

\begin{tabular}{l|c}
\multicolumn{1}{c}{ OPÇÃO DE RESPOSTA } & PESO \\
\hline Nada feito até agora & 1 \\
Pensou nas primeiras ideias de negócios & 3 \\
Fez um plano de negócios & 5 \\
Identificou uma oportunidade de mercado & 5 \\
Procurou possíveis sócios (p. ex.: colegas estudantes) & 5 \\
Comprou equipamento & 7 \\
Trabalhou no desenvolvimento de produto & 7 \\
Conversou com possíveis clientes & 7 \\
Pediu empréstimo a instituições financeiras & 8 \\
Decidiu a data da fundação & 10 \\
\hline Fonte: Sieger, Fueglistaller e Zellweger (2011) apud Relatório GUESSS Brasil (2011).
\end{tabular}

Assim, chegou-se ao cálculo do índice de empreendedorismo (Figura 5), multiplicando a porcentagem de cada opção com seu respectivo peso.

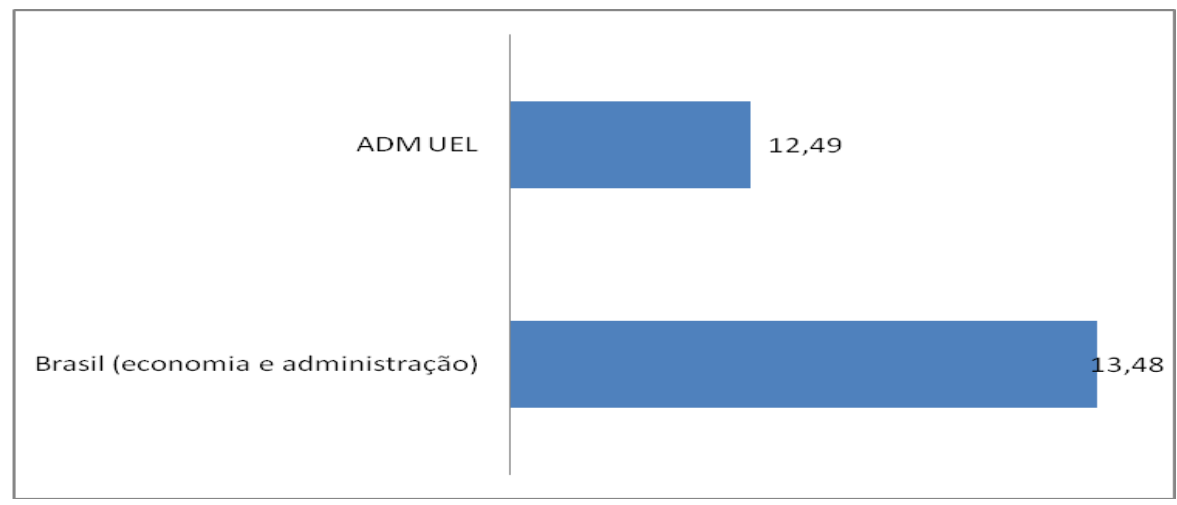

FIGURA 5 - Índice de empreendedorismo

Fonte: elaborado pelos autores (2014)

Como o índice nacional foi separado segundo as áreas de estudos e pelo objetivo deste trabalho em buscar a comparação com o Curso de Administração da UEL, utilizou-se como referência o índice brasileiro dos Cursos de Economia e Administração, já que não houve no Relatório do Estudo GUESSS Brasil um índice

VIERIA, S. F. A.; MELATTI, G. A.; NEGREIROS, L. F.; FERRI, C. M. A visão dos estudantes universitários de administração sobre empreendedorismo: comparações entre o estudo Guesss Brasil 2011 com o levantamento realizado na Universidade Estadual de LondrinaPR. Revista de Empreendedorismo e Gestão de Pequenas Empresas, v. 3, n. 3, p. 77103, 2014. 
somente para Administração. Portanto, observa-se que o BRASIL apresentou um índice de empreendedorismo superior $(13,48)$ ao verificado em ADM UEL $(12,49)$.

\section{Discussão dos Resultados}

É fácil perceber que o momento atual está propiciando cada vez mais o empreendedorismo e como afirmou Dornelas (2005, p. 22):

[...] são os empreendedores que estão eliminando barreiras comerciais e culturais, encurtando distâncias, globalizando e renovando os conceitos econômicos, criando novas relações de trabalho e novos empregos, quebrando paradigmas e gerando riqueza para a sociedade.

Ou seja, é mais comum ver pessoas querendo tornarem-se empreendedores, principalmente os universitários, que desejam depois de formados e com a experiência adquirida terem seu próprio negócio.

Como afirmaram Hisrich, Peters e Sheperd (2009, p. 41), "a educação empreendedora nunca foi tão importante em termos de cursos e pesquisa acadêmica". Nesse sentido e considerando o momento atual como a Era do Empreendedorismo, em que devem surgir cada vez mais novos empreendedores, é preciso capacitar ainda mais os candidatos a empreendedores.

Desta forma, é possível perceber que existem aspectos a serem melhorados na instituição pesquisada, objetivando facilitar o desenvolvimento da educação empreendedora e incentivo do espírito empreendedor dos universitários, fatores indispensáveis ao crescimento profissional dos acadêmicos e extremamente importantes para estimular o desenvolvimento regional e nacional.

No entanto, os resultados obtidos por meio da revisão empírica e deste estudo indicam que as instituições de ensino precisam fortalecer o currículo dos cursos de empreendedorismo, pois de acordo com Dornelas (2005), as instituições de ensino precisam fornecer entendimento sobre inovação e processo empreendedor, identificação de oportunidades, reconhecimento das habilidades empreendedoras, importância do empreendedorismo para o desenvolvimento, plano

VIERIA, S. F. A.; MELATTI, G. A.; NEGREIROS, L. F.; FERRI, C. M. A visão dos estudantes universitários de administração sobre empreendedorismo: comparações entre o estudo Guesss Brasil 2011 com o levantamento realizado na Universidade Estadual de LondrinaPR. Revista de Empreendedorismo e Gestão de Pequenas Empresas, v. 3, n. 3, p. 77103, 2014. 
de negócios, obtenção de financiamento e formas de gerenciamento para o negócio crescer

Ademais, no caso deste estudo, percebe-se, assim como no trabalho de Rocha e Bacchi (2010), uma formação incompleta no que diz respeito à formação empreendedora dos alunos. No âmbito de ADM UEL, a falta de esclarecimento sobre possíveis fontes de financiamento ou apoio financeiro oriundos da própria IES é um grande empecilho para fomentar a criação de empreendimentos.

Outro ponto deste estudo vai ao encontro do resultado obtido por Greatti et. al (2010), que identificaram que os alunos esperam uma formação voltada para a atuação em todos os tipos de empresas e contam com um ambiente de relacionamento voltado para o empreendedorismo. Em relação ao desejo dos alunos de ADM UEL, nota-se que no início da carreira a maioria prefere trabalhar em uma grande empresa ou em uma pequena ou média empresa (15,3\%). Porém, as intenções dos alunos de ADM UEL mudam após cinco anos de formados, crescendo a porcentagem dos que pretendem ter seu próprio negócio. Portanto, os alunos de ADM UEL também necessitam de uma formação ampla para atuação em diferentes tipos de negócio.

Corroborando com o trabalho de Vieira et. al (2011), vislumbra-se a possibilidade de ensinar características empreendedoras aos discentes. Mas para isso, as práticas de ensino necessitam evoluir, buscando maior aproximação e interação com o mercado, bem como maior acompanhamento durante e após a implantação dos empreendimentos oriundos de plano de negócios desenvolvidos nas disciplinas de empreendedorismo ou nos trabalhos de conclusão de curso dos alunos.

\section{Considerações Finais}

O presente trabalho realizou uma análise comparativa dos resultados obtidos no Estudo GUESSS Brasil em relação às respostas dos discentes do Curso de Administração da Universidade Estadual de Londrina (UEL), para compreender

VIERIA, S. F. A.; MELATTI, G. A.; NEGREIROS, L. F.; FERRI, C. M. A visão dos estudantes universitários de administração sobre empreendedorismo: comparações entre o estudo Guesss Brasil 2011 com o levantamento realizado na Universidade Estadual de LondrinaPR. Revista de Empreendedorismo e Gestão de Pequenas Empresas, v. 3, n. 3, p. 77103, 2014. 
questões relativas ao empreendedorismo levantadas primeiramente no estudo de âmbito nacional.

Quanto ao perfil dos alunos de Administração da UEL (ADM UEL), constatouse que a maioria dos respondentes possui menos de 25 anos de idade (81\%), 60\% são do gênero masculino e 90,84\% são solteiros. Sobre a oferta da disciplina de empreendedorismo, verificou-se que os estudantes desconheciam a oferta de ensino sobre financiamento para criação de empresas e empresas familiares. A parte mais falha da universidade estava na oferta de atividades de apoio, principalmente em relação a programas de mentoria e coaching, e na oferta de base para contato com investidores potenciais. Além disso, os discentes também desconheciam a oferta de capital inicial ou apoio financeiro oriundos da IES.

Em relação às intenções de carreira para logo após se formar, o maior percentual $(28,1 \%)$ dos respondentes do Curso de Administração da UEL afirmou que deseja trabalhar em uma grande empresa. Em seguida, apareceu o desejo de trabalhar em uma pequena ou média empresa (15,3\%) e no serviço público com 13,9\%. Percebeu-se uma irregularidade maior na intenção dos alunos do Curso de Administração da UEL em dar continuidade à empresa dos pais/parentes, que somou $8,0 \%$ contra 3,3\% dos estudantes brasileiros. É possível avaliar que essas intenções diferem do desejo desses mesmos entrevistados após cinco anos de formados.

Verificou-se, ainda, que diminui a intenção de trabalhar como funcionário em uma empresa (seja ela pequena, média ou grande) e cresce, particularmente entre os alunos de ADM UEL, a porcentagem dos que pretendem trabalhar no serviço público e, ainda mais fortemente, o intuito de ser dono do próprio negócio, seja fundando a própria empresa, uma franquia ou adquirindo uma empresa não controlada pela família. A maior motivação para escolher a carreira ou o trabalho futuro está ligada às questões relativas à realização de um sonho pessoal de crescimento e aprendizagem, seguida pelas opções financeiras.

Analisando os alunos que têm pensado em abrir seu próprio negócio, foram considerados na ADM UEL como fundadores ativos apenas 3,6\%. Já os fundadores intencionais totalizaram $31,1 \%$ e os não fundadores, $65,4 \%$. Este índice de não

VIERIA, S. F. A.; MELATTI, G. A.; NEGREIROS, L. F.; FERRI, C. M. A visão dos estudantes universitários de administração sobre empreendedorismo: comparações entre o estudo Guesss Brasil 2011 com o levantamento realizado na Universidade Estadual de LondrinaPR. Revista de Empreendedorismo e Gestão de Pequenas Empresas, v. 3, n. 3, p. 77103, 2014. 
fundadores talvez se deva à falta de oportunidade e recursos, uma vez que o maior obstáculo para empreender, apontado pela ADM UEL, está na falta de acesso ao capital de financiamento (com ou sem juros), seguido pelo risco financeiro e pela legislação do país. Mas é preciso atentar-se ao tempo de experiência que o universitário exerceu em atividades ligadas às do negócio que pretende abrir. Observou-se que a grande maioria $(56,7 \%)$ não tem experiência no setor que pretende atuar. Sendo, por isso, mais uma vez reforçada a importância das universidades em fornecer as bases do empreendedorismo por meio de projetos pedagógicos voltados a este fim.

Sobre o índice de empreendedorismo, os universitários pesquisados pelo estudo GUESSS Brasil apresentaram um índice de 13,48, enquanto que no levantamento junto aos estudantes do Curso de Administração ADM UEL esse número foi pouco inferior: 12,49. Logo, é possível concluir que os estudantes de ADM UEL apresentam fortes características empreendedoras, mas que há algumas barreiras para a aplicação dessas características, principalmente no que tange à falta de possibilidades e acesso ao capital financeiro. Além disso, verificou-se através do conhecimento sobre a oferta de disciplinas, atividades de apoio e recursos financeiros, que o curso de Administração da UEL peca mais na disponibilidade das atividades de apoio ao empreendedorismo e na oferta de capital inicial ou apoio financeiro.

Talvez, seja o momento de iniciar uma nova pesquisa junto às universidades com o intuito de verificar as possibilidades de implantarem nos currículos dos cursos de Administração uma boa disciplina de empreendedorismo, que seja capaz de instruir os futuros empreendedores. Ao mesmo tempo, levantar as condições atuais de oferta de capital inicial ou apoio financeiro aos estudantes que querem abrir seu próprio negócio, junto aos poderes públicos, bem como as indicações de melhorias que poderiam ser realizadas. Assim, uma nova pesquisa pode ser um passo estratégico para formar empreendedores cada vez mais capacitados para a imprevisível tarefa de empreender.

VIERIA, S. F. A.; MELATTI, G. A.; NEGREIROS, L. F.; FERRI, C. M. A visão dos estudantes universitários de administração sobre empreendedorismo: comparações entre o estudo Guesss Brasil 2011 com o levantamento realizado na Universidade Estadual de LondrinaPR. Revista de Empreendedorismo e Gestão de Pequenas Empresas, v. 3, n. 3, p. 77103, 2014. 


\section{Referências}

DOLABELA, F. Oficina do empreendedor. 6 ed. São Paulo: Cultura, 1999. 320 p.

DORNELAS, J. C. A. Empreendedorismo: transformando ideias em negócios. 2 ed. Rio de Janeiro: Elsevier, 2005.

ESTUDO GUESSS BRASIL. Disponível em: <http://GUESSSbrasil.org/sobre-oGUESSS-2/>. Acesso em: 16 nov. 2012.

GEM - Global Entrepreneurship Monitor. Disponível em: <http://www.gemconsortium.org/files.aspx?Ca_ID=123>. Acesso em: 14 nov. 2012.

GREATTI, L.; GRALIK, E.; VIEIRA, F. G. D.; SELA, V. M. Aprendizagem em Empreendedorismo dos Acadêmicos do Curso de Administração de uma Universidade Estadual no Sul do Brasil. In: XXXIV Encontro da ANPAD, 34, 2010, Rio de Janeiro. Anais... Rio de Janeiro, 2010. p. 1-14.

HISRICH, R. D.; PETERS, M. P.; SHEPERD, D. A. Empreendedorismo. 7 ed. Porto Alegre: Bookman, 2009.

LIMA, E.; LOPES, R.M.A.; NASSIF, V.M.J. Empreendedorismo para Todos: Desafios e Oportunidades para Aperfeiçoar a Educação Superior Brasileira. In: XXXVI Encontro da ANPAD, 36, 2012, Rio de Janeiro. Anais... Rio de Janeiro, 2012. p. 116.

LIMA, E., LOPES, R. M. A., NASSIF, V., SILVA, D. Intenções e Atividades Empreendedoras dos Estudantes Universitários - Relatório do Estudo GUESSS Brasil 2011. Grupo APOE - Grupo de Estudo sobre Administração de Pequenas Organizações e Empreendedorismo, PMDA-UNINOVE. Caderno de pesquisa, n. 2011-01. São Paulo: UNINOVE. 2011.

MACHADO, J. P. Empreendedorismo no Brasil. Curitiba: IBQP, 2010. Disponível em: < http://www.gemconsortium.org/document.aspx?id=1014>. Acesso em: 14 jan. 2013.

Relatório GUESSS Brasil 2011. Disponível em: <http://GUESSSbrasil.files.wordpress.com/2012/02/c-selo-portugues-final-relatorioGUESSS-2011.pdf>. Acesso em: 16 out. 2012.

ROCHA, E. L. de C.; BACCHI, G. A. Ensino de Empreendedorismo nos Cursos de Graduação em Administração na Cidade de Fortaleza: um estudo comparativo dos conteúdos e instrumentos pedagógicos. In: XXXIV Encontro da ANPAD, 34, 2010, Rio de Janeiro. Anais... Rio de Janeiro, 2010. p. 1-12.

VIERIA, S. F. A.; MELATTI, G. A.; NEGREIROS, L. F.; FERRI, C. M. A visão dos estudantes universitários de administração sobre empreendedorismo: comparações entre o estudo Guesss Brasil 2011 com o levantamento realizado na Universidade Estadual de LondrinaPR. Revista de Empreendedorismo e Gestão de Pequenas Empresas, v. 3, n. 3, p. 77103, 2014. 
SOUZA NETO, S. P.; ALMEIDA, K.; NUNES, A. Q.; STEFFANELLO, M. A Influência do Ensino do Empreendedorismo no Potencial Empreendedor do Aluno. In: I Encontro de Ensino e Pesquisa em Administração e Contabilidade, 1, 2007, Recife. Anais... Recife, 2007.

VIEIRA, S. F.A.; MELATTI, G. A.; OGUIDO, W. S.; PELISSON, C. Ensino de Empreendedorismo em Cursos de Administração: um Levantamento da Realidade Brasileira. In: XIV Semead, 14, 2011, São Paulo. Anais... São Paulo, 2011. p. 1-16.

Artigo recebido em: 13/02/2014. Artigo aprovado em: 16/10/2014

VIERIA, S. F. A.; MELATTI, G. A.; NEGREIROS, L. F.; FERRI, C. M. A visão dos estudantes universitários de administração sobre empreendedorismo: comparações entre o estudo Guesss Brasil 2011 com o levantamento realizado na Universidade Estadual de LondrinaPR. Revista de Empreendedorismo e Gestão de Pequenas Empresas, v. 3, n. 3, p. 77 103, 2014. 